\title{
Technology and quality of Skorup - traditional Montenegrin dairy product
}

doi: $10.15567 /$ mljekarstvo.2017.0304

\author{
Slavko Mirecki ${ }^{1 *}$, Danilo Tomić1 ${ }^{1}$ Snežana Vučinić ${ }^{2}$, Milan Marković1 ${ }^{1}$ Božidarka Markovićl \\ ${ }^{1}$ University of Montenegro, Biotechnical Faculty, M. Lalica 1, 81000 Podgorica, Montenegro \\ ${ }^{2}$ Diagnostic Veterinary Laboratory, Bul. G. Washington, 81000 Podgorica, Montenegro
}

Received - Prispjelo: 14.02.2017.

Accepted - Prihvaćeno: 25.05.2017.

\begin{abstract}
Skorup is Montenegrin traditional dairy product. Its main characteristics are extremely high content of milk fat and centuries-old technology. Due to the specific technology, high nutritional value and its historical heritage, Skorup deserves to be labelled as product with protected designation of origin (PDO) or protected geographical indication (PGI). The purpose of this study was to collect the most important data about Skorup technology and quality and to launch the process of protection. The chemical quality of raw milk was analysed using IR spectrophotometry, the number of somatic cells and total bacteria count by flow cytometry, and Skorup composition by FTIR spectrophotometry. The presence of Escherichia coli, coagulase positive staphylococci and aerobic mesophilic bacteria in Skorup was detected by standard broth base methods. All Skorup samples contained more than $80 \%$ of fat in dry matter, more than $70 \%$ dry matter, approximately $60 \%$ milk fat and $6 \%$ proteins. The sensory characteristics of all samples were excellent, and according to sensory classification, they belong to the highest classes ( $\mathrm{I}$ and $\mathrm{I}_{\mathrm{A}}$ ). However, five out of twenty samples did not meet requirements for hygienic quality, which implies the urgent need for improvement of hygiene conditions during its production.
\end{abstract}

Key words: traditional technology, chemical analysis, microbial quality, sensory quality, Skorup

\section{Introduction}

There is a wide range of traditional dairy products in Montenegro. One of them is Skorup, the fatty crust that forms on the surface during cooling of previously boiled milk. It is best known and the most popular Montenegrin dairy product characterized by the high fat content, unique technology and specific organoleptic characteristics (Mirecki and Adžić, 2000). The last phase of Skorup production is ripening in sheepskin and gives the Skorup a very specific taste, smell and consistency. Skorup that ripened in sheepskin contains more than $80 \%$ of fat in dry matter and less than $10 \%$ of proteins. It is characterised by a white to pale yellow colour, uniform and spreadable consistency, moderately salty milky-sour taste and sharper milky-sour odour (Adžić et al., 1986). It is difficult to determine to which group of dairy products Skorup belongs. Sometimes it is classified as cheese and sometimes as butter (Đorđević, 1978). Skorup contains a large amount of fat, but because of the presence of a relatively high protein content cannot be regarded as butter. Even it contains a certain amount of proteins, it cannot be considered as cheese because it is not a product of coagulation and the main role in ripening has milk fat (Mirecki and Antov, 2002).

Throughout centuries, Skorup was and is still being primarily produced in households of northern part of Montenegro. Most of it is produced in katuns - temporary settlements in mountainous regions where farmers stay with the livestock during the summer season. It is mostly produced from sheep's, cow's and mixed milk (sheep's + cow's). Organized production of Skorup in Montenegro 
began in 1908. with the establishment of Livestock Institute in Nikšić and construction of the dairy plant. Two years later, Skorup produced in Institute's dairy plant won the award at Food Fair in London (Dozet et al., 1996). Nowadays, due to the reduction of sheep population, Skorup is mostly produced from cow's milk and mixtures of cow's and sheep's milk. Unfortunately, it is hard to find Skorup made from sheep's milk only. In most households, Skorup is still produced according to centuries-old technology. During last 10 years, a few dairy craft plants in Montenegro started to produce Skorup by semiindustrial technology, but that technology does not include ripening in sheepskin.

Due to its unique production technology, high nutritional value and historical heritage, Skorup deserves to be protected by designation of origin (PDO) or by geographic indications (PGI). Skorup could meet all requirements of national Law for protected designation of origin, protected geographical indication and traditional speciality guaranteed (Off. Gazette, No. 18/11), that is harmonized with EU regulative. By Skorup protection, the unique dairy product will be preserved from oblivion, producers will have easier access to the market and higher prices of products will bring them higher profit, while consumers would be sure of the origin, the nutritional and hygienic quality of the product.

The purpose of this research was to define the main phases in production technology of Skorup, to test the quality of milk for its production, and to determine the physical and chemical composition, microbiological quality and sensory properties of Skorup.

The main aim is to collect adequate data and to launch the initiative for the PDO or PGI protection of Skorup.

\section{Materials and methods}

The research was carried out in the region of Durmitor mountain located in the north-west part of Montenegro. From this area, 60 samples of raw milk (cow's, sheep's and mixed milk), 80 samples of Skorup from wooden vat and 21 samples of Skorup from sheepskins, all made from the 3 types of milk, were collected from August - October 2015. Samples were collected from 52 individual households and 2 cooperative farms.

\section{Laboratory analysis}

Laboratory analysis included chemical, physical, cytological and microbiological quality of raw milk, chemical and hygienic quality of Skorup, and sensory evaluation of Skorup. The analyses were performed by standard and instrumental methods in laboratories, the Dairy Laboratory at Biotechnical Faculty and Diagnostic Veterinary Laboratory in Podgorica.

Analysis of milk were carried out using Combi Foss 5000 instrument (Foss Electric A/S, Denmark), which consists of two instruments: MilkoScan 4000 and Fossomatic 5000basic. MilkoScan operates on the principle of infrared spectrophotometry (IDF 141C: 2000) and analyses the content of milk fat, protein, lactose, solids non-fat and the freezing point depression of milk. Fossomatic operates on the principle of flow cytometry (MEST EN ISO 13366:2011) and analyses the number of somatic cells per millilitre of milk. Determination of total bacterial count in milk was performed by instrument BactoScan FC 100H (Foss Electric A/S, Denmark) using the method of flow cytometry (MEST EN ISO 21187:2011). The content of fat, protein and dry matter in Skorup was analysed by FTIR spectrophotometry (IDF 141C: 2000) with instrument MilkoScan FT 120 (Foss Electric A/S, Denmark). The content of fat in the dry matter was mathematically calculated (Sabadoš, 1996).

Hygienic quality of Skorup was tested in accordance with the national legislation requests for skorup/kaymak. Following tests were performed for hygienic quality testing of Skorup: for detection of Escherichia coli, ISO 16649-2:2001; coagulase positive staphylococci, MEST EN ISO 6888-2:2008; and aerobic mesophilic bacteria, MEST EN ISO 4833: 2008. Evaluation of the analysed samples was performed according to the Rules on Microbiological Criteria for Food Safety (Off. Gazette, no. 53/12).

\section{Sensory evaluation}

Five evaluators performed sensory evaluation of Skorup. The evaluation was performed according to the modified criteria of qualitative grading of sensory properties of Skorup (Konyves, 1996). Qualitative grading of sensory characteristics modified for Skorup is presented in Table 1.

Classification of Skorup based on sensory properties to the classes is presented in Table 2 (Dozet et al., 2011). 


\section{Statistical analysis}

Statistical analysis included the calculation of basic statistical parameters such as mean, minimum and maximum values and standard deviation. The statistical significance of results was tested by ANOVA with two independent variables (first - type of milk and second - type of ripening) and chemical characteristics of Skorup as dependant variables. Testing the influence of type of ripening and type of milk on Skorup quality parameters was done by LSD test. For statistical analysis of data program Statistica 12 (StatSoft) was used.

\section{Results and discussion}

\section{Traditional Skorup production technology}

Production technology was observed and recorded in households that traditionally produce Skorup from generation to generation.

Milking. Cow's, sheep's and mixed milk (cow's + sheep's) is normally used for production of Skorup. Milking is performed manually, only a few household have milking machines. A long time ago, milk was milked in the wooden buckets but, today these buckets are used for decoration and nostalgic memories only. Nowadays, metal or plastic buckets with lid are used for milking. After milking, the buckets are taken into a special building or room for milk processing, There, milk is first filtered through cheese cloth to separate mechanical impurities from milk. In order to maintain hygiene, after each use, cheese cloth is well washed in boiled water.

Milk cooking. After filtration, milk is poured into a cooking vessel (cauldron or pot). Cauldrons have capacity of 100-150 litres, and the pots 2050 litres. From mid-July, a certain amount of water is added to milk because the milk at this time of the year is so dense that can easy burn during boiling. The amount of added water gradually increases until the end of the lactation when up to $20 \%$ water can be added. In the cooking vessel, milk is gradually heated to the boiling point and then is boiled for another 10 minutes.

Milk outpouring. A vessel with long handle was used for pouring boiled milk into oblong and oval wooden dishes. The capacity of wooden dishes was 4-6 litres. After filling the wooden dish with milk, it was taken into a separate room and placed on wooden shelves where the process of milk fat separation began (Figure 1).

Formation of Skorup. Important factors for Skorup separation are temperature, humidity and air flow intensity in the room for Skorup production. The most favourable temperature is $18^{\circ} \mathrm{C}$, optimal humidity should be in the range from $75-85 \%$ and there should be a flow of air, but without draught in the room. Both, lower and higher temperatures adversely affect production process and the quality of Skorup. It is preferable to maintain milk temperature, during the first two hours at about $80{ }^{\circ} \mathrm{C}$. At this temperature, fatty globules are in liquid form and because of that they are faster allocated to the surface of milk, thereby increasing yield and improving the structure of Skorup. The moment of Skorup collection depends on temperature and humidity in the room and it could be from 1-3 days. The temperature of milk during removing crust of Skorup should not be greater than $18^{\circ} \mathrm{C}$, the optimum is between $10-15^{\circ} \mathrm{C}$. If temperature and humidity are too high, milk will coagulate in a shorter time. It is very important to avoid coagulation of milk. Otherwise, particles of the curd will be gathered together

Table 1. Qualitative scale of sensory characteristics modified for Skorup

\begin{tabular}{cccccc}
\hline & Taste & Odour & Consistency & Colour & Overall score \\
\cline { 1 - 5 } Tasters score & $1.0-3.0$ & $1.0-3.0$ & $1.0-3.0$ & $1.0-3.0$ & \\
\cline { 1 - 4 } Coefficient of correction & 3.333 & 2.000 & 0.666 & 0.666 & \\
\hline Corrected score & $3.333-10.000$ & $2.000-6.000$ & $0.666-2.000$ & $0.666-2.000$ & $6.666-20.000$ \\
\hline
\end{tabular}

Table 2. Classification of Skorup

\begin{tabular}{cccccc}
\hline Class & $\mathrm{I}_{\mathrm{A}}$ & I & II & III & IV \\
\hline Score & $18,1-20,0$ & $16,1-18,0$ & $13,1-16,0$ & $13,0-10,0$ & $<10,0$ \\
\hline Quality & excellent & very good & Good & satisfactory & not satisfactory \\
\hline
\end{tabular}


with Skorup during its removal from milk which adversely affects the quality of Skorup causing small particles of curd to corrupt consistency of Skorup. But, more important is that the increased presence of the curd protein disrupts the ripening process of Skorup and corrupts the flavour.

Skorup removal from milk. There are two ways of removing Skorup from milk. The first way is to tilt the wooden dish and to keep Skorup crust by hand so that milk is poured out, and the crust stays on the bottom of the dish. The second way is to collect the crust with a wide spoon and to transfer it to the dish for Skorup draining. The second way is better because it avoids Skorup crust to fall to the bottom of the wooden dish where mechanical impurities can be present and could contaminate Skorup. This Skorup is called "young Skorup" and it can be consumed immediately as a main course or as a supplement to other food. The shelf life of this Skorup is 1-2 days.

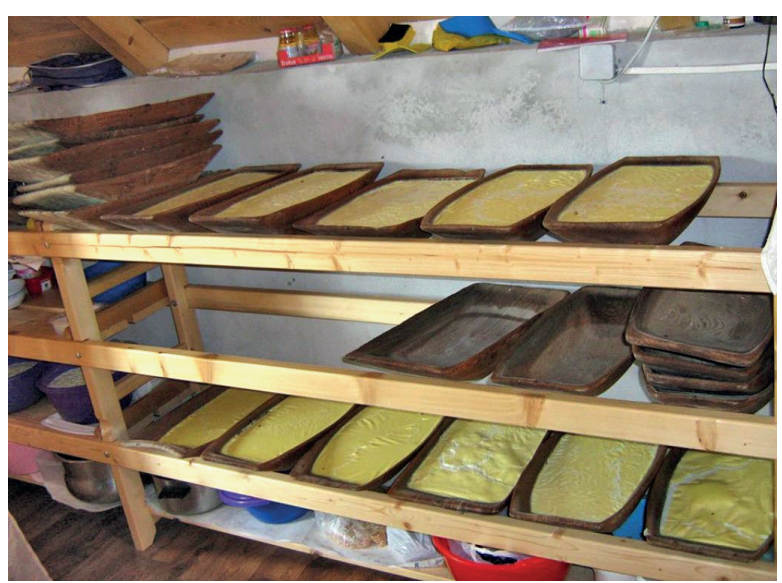

Figure 1. Formation of Skorup in wooden dishes

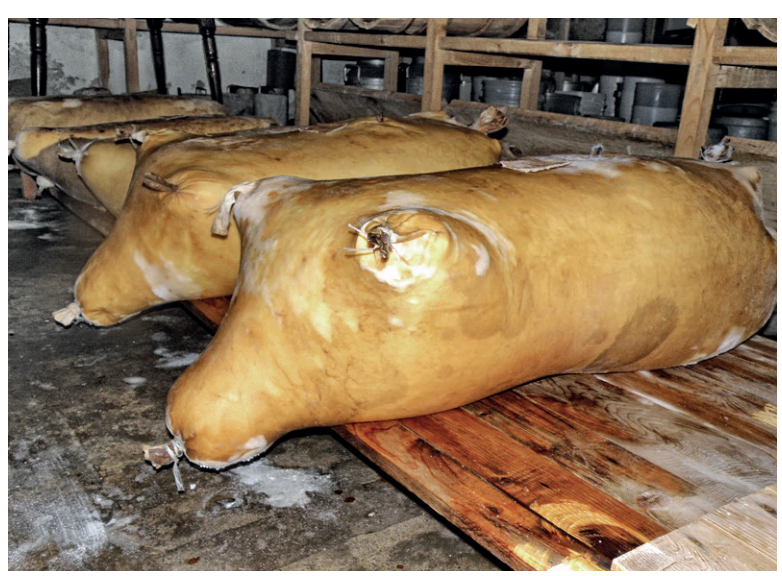

Figure 3. Skorup ripening in sheepskin
Skorup ripening in vats. Layers of young Skorup are stacked in a special vessel, in which they stay for one to two hours to extract any excess of milk. Then, the drained Skorup layers are placed, layer by layer, in the prepared wooden vat. Each layer is salted by dry salt. The amount of added salt is approximately 2.0 to $2.5 \%$. Vats are mostly made of wood and have a capacity of 30 to $60 \mathrm{~kg}$. There is a small hole at the bottom of vats which is used to drain liquids formed by the further draining of Skorup. The hole is periodically opened and after the full drainage of liquid is closed again. In households with a small production, vats filling usually take 5-10 days. Households with a higher production would fill one vat in 1-3 days. Shorter filling time of vats makes better structure, salinity, colour, taste and other sensory qualities of Skorup. When the vats are filled, they are covered with cheese cloth and taken into a room for maturing (Figure 2). The room must be well ventilated, protected from direct sunlight and cold, with the temperature of $8-15^{\circ} \mathrm{C}$. After $20-30$ days, Skorup is ripe and it is called "matured Skorup".

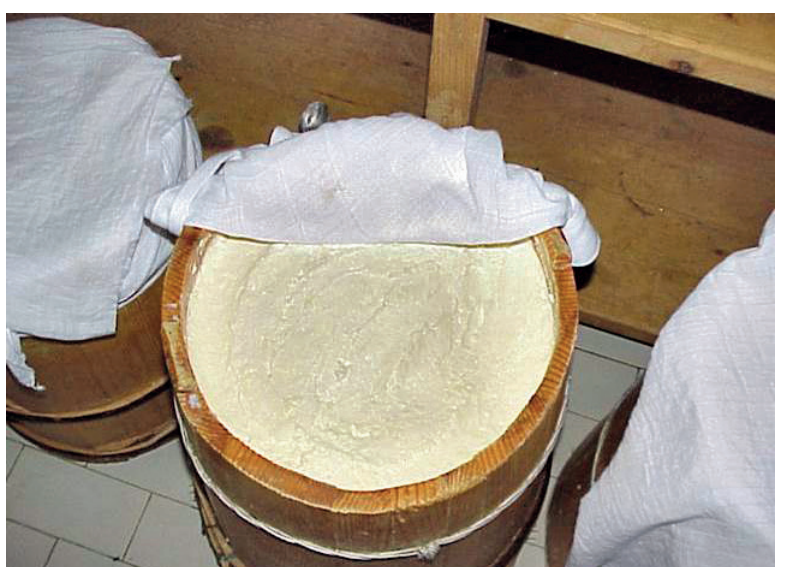

Figure 2. Skorup ripening in vat

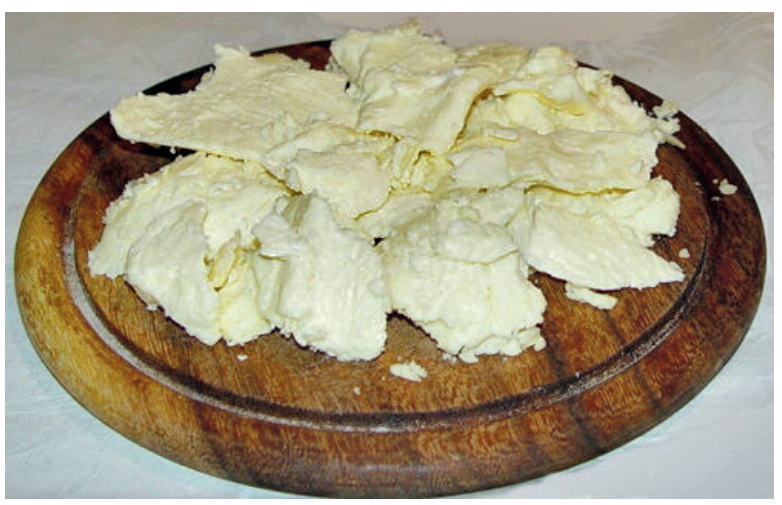

Figure 4. Old Skorup 
Skorup ripening in sheepskin. To produce "old Skorup" or "sheepskin Skorup", it is necessary to transfer Skorup from wooden vats to sheepskin. Sheepskin could be the skin from sheep or lamb, and rarely from a young goat. The preparation of skins is very complex and long process. During filling of sheepskin, Skorup has to be compacted as much as possible because the air in sheepskin needs to be ejected in order to create anaerobic conditions that are necessary for ripening of Skorup. Compaction of Skorup is done manually, by the fist. Before filling, all openings but one (usually the neck) on the sheepskin should be closed by binding. The Skorup filling is done via neck opening. When sheepskin is filled, the remaining opening is closed. After that, sheepskin is transferred to the room for ripening (Figure 3). This room must meet the same environmental conditions as for Skorup ripening in vats. For both ways of ripening, the same room is most commonly used. In order to achieve the desired level of ripening, Skorup must ripen in sheepskin at least for two months. For more piquant taste ripening period is longer, it can go up to six months or longer. It is necessary to maintain the surface of sheepskin during ripening, so every other day during the first month of ripening sheepskins is rolled over and cleaned. After one month, turning over and cleaning the sheepskin is done every 4-5 days.

Skorup storage. Skorup in vats and sheepskins is kept in the coldest room in the house - usually basements. If sheepskin is well prepared, the conditions of ripening are optimal and if there were no errors in the production technology, Skorup can be stored up to a year without losing the quality and sensory properties. Thereby taste and odour become even more piquant.

\section{Raw milk quality}

All milk samples were sampled from the cooking vessels just before the start of heating the milk. Since the number of households that produce Skorup from sheep's milk is less than the number of households using cow's and mixed milk, the number of analysed sheep's milk samples are the least numerous. The quality of all three types of milk is presented in Table 3.

The values of chemical quality parameters for all three types of milk were in the range that corresponds to the period of lactation they originated from, August-September. It was observed that the ratio of sheep's and cow's milk at mixed milk varied from 20:80 to 40:60, really 50:50. The most common ratio was approx. 30:70.

The number of somatic cells is correlated with the health of animals. If only the average value of the number of somatic cells in tested milk samples is considered (Table 4), it could be concluded

Table 4. Somatic cells and total bacteria count in raw milk for Skorup production

\begin{tabular}{ccccc}
\hline \multirow{2}{*}{ Trait } & & \multicolumn{3}{c}{ Milk } \\
\cline { 2 - 5 } & & Cow's & Sheep's & Mixed \\
\hline \multirow{3}{*}{$\begin{array}{c}\text { Somatic cells } \\
(\mathrm{x} \mathrm{10})\end{array}$} & $\mathrm{N}$ & 30 & 10 & 20 \\
\cline { 2 - 5 } & $\mathrm{X}$ & 1001 & 1094 & 1041 \\
\cline { 2 - 5 } & $\mathrm{X}_{\min }$ & 107 & 259 & 466 \\
\hline & $\mathrm{X}_{\max }$ & 5451 & 2488 & 3338 \\
\hline \multirow{2}{*}{$\begin{array}{c}\text { CFU }^{\mathrm{y}} \\
(\mathrm{x} \mathrm{103})\end{array}$} & $\mathrm{N}$ & 30 & 10 & 20 \\
\cline { 2 - 5 } & $\mathrm{X}_{\min }$ & 739 & 103 & 204 \\
\cline { 2 - 5 } & $\mathrm{X}_{\max }$ & 9627 & 238 & 256 \\
\hline
\end{tabular}

${ }^{\mathrm{C}} \mathrm{CFU}$ - colony forming units

Table 3. Quality of raw milk for Skorup production

\begin{tabular}{|c|c|c|c|c|c|c|c|}
\hline Milk & $\mathrm{n}$ & & $\begin{array}{c}\text { Fat } \\
\%\end{array}$ & $\begin{array}{c}\text { Proteins } \\
\%\end{array}$ & $\begin{array}{c}\text { Lactose } \\
\%\end{array}$ & $\begin{array}{c}\mathrm{SNF}^{\mathrm{a}} \\
\%\end{array}$ & $\begin{array}{l}\mathrm{FPD}^{\mathrm{b}} \\
-\mathrm{C}^{\circ}\end{array}$ \\
\hline \multirow{2}{*}{ Cow's } & \multirow{2}{*}{30} & $\bar{x}$ & 3.92 & 3.35 & 4.51 & 8.59 & 0.532 \\
\hline & & $\mathrm{SD}$ & 0.21 & 0.13 & 0.11 & 0.19 & 0.009 \\
\hline \multirow{2}{*}{ Sheep's } & \multirow{2}{*}{10} & $\bar{x}$ & 8.41 & 7.94 & 4.33 & 12.76 & 0.559 \\
\hline & & $\mathrm{SD}$ & 0.70 & 0.67 & 0.27 & 0.78 & 0.017 \\
\hline \multirow{2}{*}{ Mixed } & \multirow{2}{*}{20} & $\bar{x}$ & 5.33 & 4.56 & 4.42 & 9.71 & 0.542 \\
\hline & & $\mathrm{SD}$ & 0.62 & 0.51 & 0.12 & 0.42 & 0.007 \\
\hline
\end{tabular}

${ }^{a} \mathrm{SNF}$ - solids non-fat; bPPD - freezing point depression 
that udder health was not good, especially cow's (1.001.000 cells $/ \mathrm{mL})$. The situation considering somatic cells count was alarming on three cow farms and farm owners were immediately informed about the results. But, there were several cow farms where the number of cells was less than $200.000 / \mathrm{mL}$ and for the rest of the farms, cell number was acceptable. The limit value of somatic cells in sheep's milk is not defined in Montenegro. If we consider that many authors suggest that this limit is 1.000 .000 cells in $1 \mathrm{~mL}$ of milk (Antunac et al., 1999), then, the quality of milk and thus the state of sheep's udder health in this study, is satisfactory.

The most common causes of increased number of microorganisms are inadequate conditions for animal breeding, irregular milking, unhygienic conditions and improper milking procedures with milk after milking. According to the National Regulations (Off. Gazette, no. 14/2009), raw cow's milk should have bacteria count less than $100.000 \mathrm{CFU} / \mathrm{mL}$; other milk less than 1.500.000, and the milk for cheese production, without pasteurisation, less than 500.000. Despite poor production conditions in katuns (lack of water), results in this study showed that $70 \%$ of raw cow's milk and $100 \%$ of sheep's and mixed raw milk are in accordance with requests prescribed in National Regulation.

The above results for average composition of the three types of milk for the content of fat and protein are higher than those listed by Dozet et al.

Table 5. Chemical composition of Skorup ripened in wooden vats

\begin{tabular}{|c|c|c|c|c|c|c|}
\hline Skorup & $\mathrm{n}$ & & $\begin{array}{l}\text { Fat } \\
\%\end{array}$ & $\begin{array}{c}\text { Proteins } \\
\quad \%\end{array}$ & $\begin{array}{c}\text { Dry } \\
\text { matter } \\
\%\end{array}$ & $\begin{array}{c}\text { Fat in } \\
\text { dry } \\
\text { matter } \\
\%\end{array}$ \\
\hline \multirow{3}{*}{$\begin{array}{l}\text { Cow's } \\
\text { milk }\end{array}$} & \multirow{3}{*}{25} & 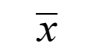 & 51.79 & 5.79 & 64.08 & 82.47 \\
\hline & & $\mathrm{X}_{\min }$ & 40.15 & 4.25 & 52.26 & 76.37 \\
\hline & & $\mathrm{X}_{\max }$ & 61.35 & 8.65 & 72.46 & 86.45 \\
\hline \multirow{3}{*}{$\begin{array}{l}\text { Sheep's } \\
\text { milk }\end{array}$} & \multirow{3}{*}{20} & $\bar{x}$ & 53.59 & 6.61 & 66.28 & 82.51 \\
\hline & & $\mathrm{X}_{\min }$ & 40.52 & 5.09 & 58.04 & 78.28 \\
\hline & & $\mathrm{X}_{\max }$ & 63.43 & 5 & 75.21 & 87.36 \\
\hline \multirow{3}{*}{$\begin{array}{l}\text { Mixed } \\
\text { milk }\end{array}$} & \multirow{3}{*}{35} & $\bar{x}$ & 52.72 & 5.80 & 63.22 & 83.55 \\
\hline & & $\mathrm{X}_{\min }$ & 7 & 461 & 47.98 & 79.60 \\
\hline & & $\mathrm{X}_{\max }$ & 65.04 & 7.51 & 76.14 & 7.01 \\
\hline
\end{tabular}

(1996), Dozet et al. (2004), Adžić et al. (1986) and Mirecki and Adžić (2000). The reason for this, most likely, is fact that milk sampling was done during second part of lactation, the period when the values of these parameters are very high. Skorup production starts at the second part of lactation, because at the beginning of lactation milk is used for lambs and calves feeding.

\section{Chemical quality of Skorup ripened in wooden vats}

The results of chemical analysis of Skorup ripened in wooden vats are presented in Table 5.

As it was expected, the highest content of fat, proteins and dry matter had the Skorup made from sheep's milk. But, the content of fat in dry matter in Skorup from sheep's milk was lower than in mixed milk Skorup and almost equal to cow's milk Skorup. The reason for this could be the fact that fat globules of sheep's milk fat separated more slowly on the surface of milk than fat globules of cow's milk. Experience from different households showed that duration of separation of fat takes the same period of time for both types of milk and as a result, more milk fat is extracted from the cow's than from the sheep's milk. Also, the quality of Skorup produced from mixed milk is largely influenced by the different ratio of sheep's and cow's milk. This ratio varies from household to household, but as it is mentioned before, the most common ratio is $70 \%$ cow's and $30 \%$ sheep's milk.

Table 6. Chemical composition of Skorup ripened in sheepskin

\begin{tabular}{|c|c|c|c|c|c|c|}
\hline Skorup & $\mathrm{n}$ & & $\begin{array}{l}\text { Fat } \\
\%\end{array}$ & $\begin{array}{l}\text { Proteins } \\
\quad \%\end{array}$ & $\begin{array}{c}\text { Dry } \\
\text { matter } \\
\%\end{array}$ & $\begin{array}{c}\text { Fat in } \\
\text { dry } \\
\text { matter } \\
\%\end{array}$ \\
\hline \multirow{3}{*}{$\begin{array}{l}\text { Cow's } \\
\text { milk }\end{array}$} & \multirow{3}{*}{5} & $\bar{x}$ & 59.98 & 6.53 & 72.04 & 83.21 \\
\hline & & $\mathrm{X}_{\min }$ & 48.07 & 5.57 & 59.87 & 80.29 \\
\hline & & $\mathrm{X}_{\text {max }}$ & 64.67 & 7.36 & 78.03 & 86.16 \\
\hline \multirow{3}{*}{$\begin{array}{l}\text { Sheep's } \\
\text { milk }\end{array}$} & \multirow{3}{*}{5} & $\bar{x}$ & 60.07 & 6.08 & 69.37 & 86.69 \\
\hline & & $\mathrm{X}_{\min }$ & 50.93 & 5.92 & 58.57 & 83.96 \\
\hline & & $\mathrm{X}_{\text {max }}$ & 68.01 & 6.28 & 81.00 & 87.98 \\
\hline \multirow{3}{*}{$\begin{array}{l}\text { Mixed } \\
\text { milk }\end{array}$} & \multirow{3}{*}{10} & $\bar{x}$ & 61.42 & 6.52 & 73.89 & 83.07 \\
\hline & & $X_{\text {min }}$ & 48.61 & 5.28 & 60.10 & 79.47 \\
\hline & & $\mathrm{X}_{\text {max }}$ & 70.55 & 7.85 & 80.82 & 88.45 \\
\hline
\end{tabular}


If the results of the current study were compared to the results of one of the oldest scientific research about Skorup from Montenegro (Laxa cit. Gutschy, 1927), it is apparent that content of dry matter was lower, and milk fat was almost equal. Fat content and fat in a dry matter of the analysed samples are in accordance with the content of the same parameters specified by Adžić et al. (1986), however, the content of dry matter is lower. Skorup analysed by Dozet et al. (1996) had a higher content of dry matter and fat, but the content of fat in dry matter is almost equal. A wide variation and differences in the content of fat, dry matter and fat in dry matter were found among results from this study and results from other studies. These differences are consequences of the absence of standardised technology of Skorup production. Comparing the quality of Skorup from the research with similar products from Serbia (Đorđević, 1978; Mijačević et al., 1990), Bosnia and Herzegovina (Stanišić et al., 1990; Dozet et al., 2011) and Turkey (Akalin, 2006), almost the same differences and variations in quality were observed.

\section{Chemical quality of Skorup ripened in sheepskin}

The results of chemical analysis of Skorup ripened in sheepskin are presented in Table 6 .

The variations and differences in the content of fat, dry matter and fat in the dry matter are also present in Skorup ripened in sheepskin. The content of the above mentioned parameters was higher than in Skorup from wooden vats. Especially noticeable was the extremely high content of fat in the dry matter. All samples, except one, contained more than $80 \%$ fat in the dry matter, and one was over $88 \%$. Still, the variation of the content of all quality parameters indicated the absence of standardised Skorup production technology.

Skorup ripened in sheepskin is unique and it is not known that such a product is produced elsewhere. Unfortunately, a small number of scientific papers about Skorup could be found even in its country of origin - Montenegro. The results of this study are in compliance with results of Mirecki and Adžić (2000), and Konatar and Dozet (2008).

For evaluating the influence of the type of ripening and the type of milk on the fat, protein, dry matter and fat in dry matter content in Skorup,
ANOVA with two independent variables (type of milk and type of ripening) and chemical characteristics of Skorup as dependant variables, was used.

The interaction between the types of ripening and types of milk is not statistically significant for the fat and dry matter content in Skorup $(\mathrm{p}=0.846$; $p=0.108$ ). However, the content of both parameters was affected by the type of ripening, but not by type of milk. If we compare data from Table 5 and Table 6 , it can be seen that the fat content and dry matter content in Skorup ripened in the sheepskin was higher than in Skorup ripened in wooden vat, and these differences are statistically significant according to the t-test $(\mathrm{t}(99)=-5.29 ; \mathrm{p}<0.01$ and $t(99)=-5.71 ; p<0.01$, respectively).

Also, the analysis of variance indicated that the interaction between types of ripening and types of milk were statistically significant for the contents of protein and fat in the dry matter $(\mathrm{p}=0.007$ and $\mathrm{p}=0.012$ ). For types of Skorup that were ripening in wooden vats, it was found that Skorup made from sheep's milk has protein content higher than Skorup made from cow's milk and mixed milk. LSD test in Table 7. showed that these differences are of high statistical significance $(\mathrm{p}<0.01)$. Also, the same type of Skorup containing a higher content of protein than Skorup made from sheep's and mixed milk ripened in sheepskin, and the differences were statistically significant $(p<0.05)$. The content of fat in dry matter in Skorup made from sheep's milk ripened in wooden vats was higher than in Skorup made from sheep's milk ripened in sheepskin. The difference has high statistical significance $(\mathrm{p}<0.01)$. Also, the same type of Skorup had more fat in the dry matter than Skorup made from cow's and mixed milk ripened in sheepskin, but those differences were of statistical significance at the level of $\mathrm{p}<0.05$.

\section{Microbial quality of Skorup}

The results of microbial tests of Skorup ripened in sheepskin are shown in Table 8.

A total of 20 samples were analysed for presence of Escherichia coli, coagulase-positive staphylococci and aerobic mesophilic bacteria. Evaluation of the analysed samples was carried out by the national Regulations (Off. Gazette, no. 53/12) and The Guide for microbial criteria for food safety. 
Based on the two limits, $\mathrm{m}$ and $\mathrm{M}$, the obtained results were interpreted in three possible ways - as satisfactory, acceptable and unsatisfactory. All of 20 samples were satisfactory for Escherichia coli presence. Sixteen samples were satisfactory and 4 were within acceptable limits. As for the presence of coagulase-positive staphylococci, 4 samples were satisfactory, 15 samples were acceptable, and one sample was unsatisfactory. The number of colonies of aerobic mesophilic bacteria was satisfactory in 7 samples, acceptable in 9, and 4 samples did not meet the requirements of hygienic quality. Poor conditions for hygiene maintenance in the premises for Skorup products, lack of water in katuns, inadequate cleaning of equipment, and especially the fact that the majority of procedures during production are done manually, are the main reasons that some of the analysed samples did not comply with national regulations regarding the hygienic quality. To fulfill all the conditions for Skorup protection by PDO, it is necessary to improve its hygienic quality. For this, it is necessary to educate producers about hygiene, measures and proper procedures in the process of milking, as well as provide adequate hygienic conditions and equipment for Skorup production.

Mirecki and Adžić (2000) found that 24.68 \% of Skorup samples from the sheepskins did not meet standards of hygienic quality. The contamination happened, mostly, during Skorup transfer from wooden vats to sheepskin.

Table 7. Influence of type of ripening and type of milk on Skorup quality parameters (LSD test)

\begin{tabular}{|c|c|c|c|c|c|c|c|c|c|}
\hline & & $\begin{array}{l}\text { Type of } \\
\text { Ripening }\end{array}$ & $\begin{array}{c}\text { Type of } \\
\text { Milk }\end{array}$ & $1^{a}$ & 2 & 3 & 4 & 5 & 6 \\
\hline \multirow{6}{*}{ 空 } & 1 & Vat & Cow's & - & 0.346 & 0.578 & $0.009 * *$ & $0.008^{* *}$ & $0.000^{* *}$ \\
\hline & 2 & Vat & Sheep's & 0.346 & - & 0.624 & $0.046^{*}$ & $0.043^{*}$ & $0.001^{* *}$ \\
\hline & 3 & Vat & Mixed & 0.578 & 0.624 & - & $0.018^{*}$ & $0.017^{*}$ & $0.000^{* *}$ \\
\hline & 4 & Sheepskin & Cow's & $0.009 * *$ & $0.046^{*}$ & $0.018^{*}$ & - & 0.981 & 0.675 \\
\hline & 5 & Sheepskin & Sheep's & $0.008^{* *}$ & $0.043^{*}$ & $0.017^{*}$ & 0.981 & - & 0.695 \\
\hline & 6 & Sheepskin & Mixed & $0.000^{* *}$ & $0.001^{* *}$ & $0.000^{* *}$ & 0.675 & 0.695 & - \\
\hline \multirow{6}{*}{ 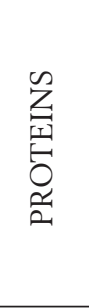 } & 1 & Vat & Cow's & - & $0.000^{* *}$ & 0.977 & 0.214 & 0.627 & 0.095 \\
\hline & 2 & Vat & Sheep's & $0.000^{* *}$ & - & $0.000^{* *}$ & 0.079 & $0.013^{*}$ & $0.019^{*}$ \\
\hline & 3 & Vat & Mixed & 0.977 & $0.000^{* *}$ & - & 0.208 & 0.630 & 0.084 \\
\hline & 4 & Sheepskin & Cow's & 0.214 & 0.079 & 0.208 & - & 0.555 & 0.996 \\
\hline & 5 & Sheepskin & Sheep's & 0.627 & $0.013^{*}$ & 0.630 & 0.555 & - & 0.492 \\
\hline & 6 & Sheepskin & Mixed & 0.095 & $0.019^{*}$ & 0.084 & 0.996 & 0.492 & - \\
\hline \multirow{6}{*}{ 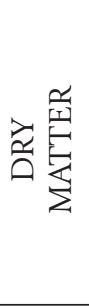 } & 1 & Vat & Cow's & - & 0.071 & 0.801 & $0.000^{* *}$ & $0.037^{*}$ & $0.000^{* *}$ \\
\hline & 2 & Vat & Sheep's & 0.071 & - & 0.089 & $0.016^{*}$ & 0.333 & $0.001^{* *}$ \\
\hline & 3 & Vat & Mixed & 0.801 & 0.089 & - & $0.000^{* *}$ & $0.046^{*}$ & $0.000^{* *}$ \\
\hline & 4 & Sheepskin & Cow's & $0.000^{* *}$ & $0.016^{*}$ & $0.000^{* *}$ & - & 0.248 & 0.965 \\
\hline & 5 & Sheepskin & Sheep's & $0.037^{*}$ & 0.333 & $0.045^{*}$ & 0.248 & - & 0.191 \\
\hline & 6 & Sheepskin & Mixed & $0.000^{* *}$ & $0.001^{* *}$ & $0.000^{* *}$ & 0.965 & 0.191 & - \\
\hline \multirow{6}{*}{ 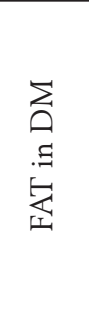 } & 1 & Vat & Cow's & - & 0.106 & 0.295 & 0.636 & $0.010^{*}$ & 0.547 \\
\hline & 2 & Vat & Sheep's & 0.106 & - & $0.007^{* *}$ & 0.152 & $0.000^{* *}$ & 0.062 \\
\hline & 3 & Vat & Mixed & 0.295 & $0.007^{* *}$ & - & 0.927 & $0.038^{*}$ & 0.869 \\
\hline & 4 & Sheepskin & Cow's & 0.636 & 0.152 & 0.927 & - & 0.101 & 0.980 \\
\hline & 5 & Sheepskin & Sheep's & $0.010^{*}$ & $0.001^{* *}$ & $0.038^{*}$ & 0.101 & - & 0.052 \\
\hline & 6 & Sheepskin & Mixed & 0.547 & 0.062 & 0.869 & 0.980 & 0.052 & - \\
\hline
\end{tabular}

${ }^{*} \mathrm{p}<0.05 ;{ }^{* *} \mathrm{p}<0.01$

a- numeric codes are a combinations of types of ripening and types of milk, same as in second column of the table 


\section{Sensory evaluation of Skorup}

The sensory analyses were performed on 15 samples of Skorup which ripened in sheepskin. The samples were divided into three groups: 5 samples from cow's, 5 from sheep's and 5 from mixed milk. The results of sensory evaluation of Skorup are presented in Table 9.

Top rated Skorup was the Skorup from sheep's milk, which got 19.34 points, out of 20. According to the classification, Skorup from sheep's milk belongs to $I_{A}$ class, which means that it has excellent sensory characteristics. Skorup made from mixed milk got 18.86 points and also belongs to the class $\mathrm{I}_{\mathrm{A}}$. The lowest score had Skorup from cow's milk (16.27). However, despite the lowest score Skorup from cow's milk belong to class I, just 1.83 points less than $\mathrm{I}_{\mathrm{A}}$ class.
Described by words, sensory characteristics were as follows:

- Taste - specific, mild milky-sour, very pleasant, moderately salty. Only one sample had a slightly bitter taste,

- Colour - depending on the type of milk from which Skorup is produced, it was white, pale yellow and yellow,

- Odour - mild milky-sour, pleasant. Two samples had smell of boiled milk,

- Consistency - uniform, well spreadable. Two samples were mildly layered and crumbly.

Dozet et al. (2011) made Skorup-Kaymak classification based on sensory traits using the international standards of the Codex Alimentarius and other modern classification. According to this classification, Skorup samples from this study belong to the extra class.

Table 8. Microbial quality of Skorup ripened in sheepskin

\begin{tabular}{|c|c|c|c|c|c|c|c|}
\hline \multirow{2}{*}{$\begin{array}{c}\text { Microbial } \\
\text { parameters }\end{array}$} & \multirow{2}{*}{$\mathrm{n}$} & \multirow{2}{*}{ Unit } & \multicolumn{2}{|c|}{ Limits } & \multirow{2}{*}{\multicolumn{3}{|c|}{ Out of limits }} \\
\hline & & & $\mathrm{m}$ & M & & & \\
\hline \multirow[b]{2}{*}{ Escherichia coli } & \multirow[b]{2}{*}{20} & $\mathrm{CFU} / \mathrm{g}$ & 10 & $10^{2}$ & & & \\
\hline & & $\begin{array}{c}\text { results } \\
\text { (number of samples) }\end{array}$ & $\begin{array}{c}<10(15) \\
10(1)\end{array}$ & $\begin{array}{l}50(1) \\
60(1) \\
90(2)\end{array}$ & & - & \\
\hline \multirow{2}{*}{$\begin{array}{l}\text { Coagulase-positive } \\
\text { staphylococci }\end{array}$} & \multirow[b]{2}{*}{20} & $\mathrm{CFU} / \mathrm{g}$ & 10 & $10^{2}$ & & & \\
\hline & & $\begin{array}{c}\text { results } \\
\text { (number of samples) }\end{array}$ & $<10(4)$ & $<100(15)$ & & $360(1)$ & \\
\hline \multirow{2}{*}{$\begin{array}{c}\text { Aerobic mesophilic } \\
\text { bacteria }\end{array}$} & \multirow{2}{*}{20} & $\mathrm{CFU} / \mathrm{g}$ & $10^{3}$ & $10^{4}$ & $10^{6}$ & $10^{7}$ & $10^{8}$ \\
\hline & & (number of samples) & (7) & (9) & (4) & - & - \\
\hline
\end{tabular}

Table 9. Sensory evaluation of Skorup

\begin{tabular}{ccccccc}
\hline \multirow{2}{*}{ Skorup } & Score & Taste & Odour & Consistency & Colour & Overall \\
\cline { 2 - 6 } & Max. & 10.00 & 6.00 & 2.00 & 2.00 & 20.00 \\
\hline \multirow{2}{*}{ Cow's milk } & Average & 2.47 & 2.55 & 2.86 & 2.69 & \\
\cline { 2 - 7 } & Corrected & 8.24 & 5.11 & 1.23 & 1.69 & $\mathbf{1 6 . 2 7}$ \\
\hline \multirow{2}{*}{ Sheep's milk } & Average & 2.89 & 2.88 & 2.95 & 3.00 & \\
\cline { 2 - 7 } & Corrected & 9.64 & 5.76 & 1.96 & 1.99 & 19.35 \\
\hline \multirow{2}{*}{ Mixed milk } & Average & 2.86 & 2.75 & 2.90 & 2.85 & \\
\cline { 2 - 7 } & Corrected & 9.54 & 5.50 & 1.93 & 1.89 & 18.86 \\
\hline
\end{tabular}




\section{Conclusions}

Skorup was and still is one of the most popular and the finest traditional dairy product in Montenegro. Raw milk for Skorup production was of good chemical quality, regardless of the type. The fat content in raw milk ranged from $3.92 \%$ (cow's milk) to $8.41 \%$ (sheep's milk), and proteins from $3.35 \%$ (cow's milk) to $7.94 \%$ (sheep's milk). But, relatively high number of bacteria, particularly in cow's milk $(1,001$ million $\mathrm{CFU} / \mathrm{mL})$ indicates poor hygienic conditions during milking and inadequate handling with milk after the milking. In general, nutritional value of Skorup was high. The content of fat in dry matter in Skorup ripened in sheepskin varied from $83.07 \%$ (mixed milk) up to $86.69 \%$ (sheep's milk) and the content of proteins from $6.08 \%$ (sheep's milk) to $6.53 \%$ (cow's milk). According to the results of sensory evaluation, all samples of Skorup have excellent sensory characteristics and they belong to highest quality classes $\left(\mathrm{I}_{\mathrm{A}}\right.$ and $\left.\mathrm{I}\right)$. Skorup from sheep's milk was top rated, than Skorup from mixed milk, and the lowest score had Skorup from cow's milk. Microbial analysis of Skorup showed that one out of twenty samples was unsatisfactory due to the presence of coagulase-positive staphylococci and four samples due to the presence of aerobic mesophilic bacteria. The results of microbial analysis of raw milk and Skorup ripened in sheepskin indicated that there is a need for improvement of hygienic conditions at all stages of Skorup production.

Due to historical heritage, well-determined production area, unique and specific technology, high nutritional value and excellent sensory characteristics, Skorup deserves to be protected by designation of origin (PDO). However, when meets all hygiene aspects, Skorup will fulfil the requirements of national Law (Official Gazette, No. 18/11), and then the procedures of its protection could be initiated.

\section{Acknowledgements}

This study was funded by Ministry of Science and Ministry of Education of Montenegro through Higher Education and Research for Innovation and Competitiveness Project (HERIC): Valorising Montenegrin Katuns through sustainable development of agriculture and tourism - KATUN. (MNE-HERIC-81 180-KATUN), www.katun.me.

\section{Tehnologija i kvaliteta skorupa - tradicionalnog crnogorskog mliječnog proizvoda}

\section{Sažetak}

Skorup je crnogorski tradicionalni mliječni proizvod. Njegove glavne karakteristike su izuzetno visok udjel mliječne masti i stoljećima stara tehnologija. Zbog specifične tehnologije, visoke hranjive vrijednosti i povijesne baštine, skorup zaslužuje da bude zaštićen kao PDO ili PGI. Svrha ovog istraživanja je prikupiti najvažnije podatke o tehnologiji skorupa i njegovoj kvaliteti kako bi se inicirao postupak zaštite. Kemijska kvaliteta sirovog mlijeka analizirana je pomoću IR spektrometrije, broj somatskih stanica i broj mikroorganizama protočnom citometrijom, a sastav skorupa FTIR spektrofotometrijom. Prisutnost Escherichia coli, koagulaza pozitivne stafilokoke i aerobnih mezofilnih bakterija u skorupu određena je standardnim mikrobiološkim metodama. Svi uzorci skorupa su sadržavali više od $80 \%$ masti u suhoj tvari, više od $70 \%$ suhe tvari, i oko $60 \%$ mliječne masti i $6 \%$ proteina. Prema senzorskoj ocjeni i klasifikaciji, svi uzorci su odlične kvalitete i pripadaju I i I klasi. No, pet od dvadeset uzoraka nije zadovoljilo uvjete higijenske kvalitete, što ukazuje da je neophodno raditi na poboljšanju higijenskih uvjeta tijekom njegove proizvodnje.

\author{
Ključne riječi: tradicionalna tehnologija, \\ kemijska, mikrobiološka i \\ senzorska kvaliteta skorupa
}




\section{References}

1. Adžić, N., Dozet, N., Stanišić, M. (1986): Tehnologija i kvalitet crnogorskog skorupa. Mljekarstvo 36 (6), 163134.

2. Akalin, A.S., Gönç, S., Ünal, G. and Ökten, S. (2006): Determination of some chemical and microbiological characteristics of Kaymak. Grasas Y Aceites 57 (4), 429-432.

3. Dozet, N., Adžić, N., Živić, N. (1996): Autohtoni mlječni proizvodi. Poljoprivredni institut-Podgorica, SILMIR, Beograd.

4. Dozet, N., Maćej, O., Jovanović, S. (2004): Autohtoni mlječni proizvodi osnova za razvoj specifičnih, orginalnih mlječnih prerađevina $\mathrm{u}$ savremenim uslovima. Biotehnologija u stočarstvu 20 (3-4), 31-48.

5. Dozet, N., Pandurević, S., Jovanović, S., Borovčanin, T. (2011): Romanijski skorup-kajmak. Univerzitet u Istočnom Sarajevu - Poljoprivredni fakultet.

6. Đorđević, J. (1978): Kajmak-pitanje klasifikacije i propisa o kvalitetu. Mljekarstvo 28, 37-140.

7. Gutschy, L. (1927): Contribution a l'etude de la mycology du "Kajmak". Le Lait 62, 113-126. doi: https://doi.org/10.1051/lait:1927628

8. IDF Standard 141C (2000): International Dairy Federation. (2000): Whole milk. Determination of milk fat, protein and lactose content - Guide for the operation of midinfra-red instruments.

9. ISO 16649-2 (2001): Microbiology of food and animal feeding stuffs - Horizontal method for the enumeration of beta-glucuronidase-positive Escherichia coli - Part 2: Colony-count technique at 44 degrees $\mathrm{C}$ using 5-bromo4-chloro-3-indolyl beta-D-glucuronide.

10. Konatar, Z., Dozet, N. (2008): Autohtona prerada mlijeka na polimsko-vasojevićkom području. Zbornik radova simpozijuma "Mleko i proizvodi od mleka", 41-45.

11. Konyves, T. (1996): Smanjenje holesterola u mlečnim proizvodima pomoću jogurtnih kultura. Doktorska disertacija (disertation). Univerzitet Novi Sad, Poljoprivredni fakultet.
12. MEST EN ISO 13366 (2011): Milk - Enumeration of somatic cells - Part 2: Guidance on the operation of fluoro-opto-electronic counters.

13. MEST EN ISO 21187 (2011): Milk - Quantitative determination of bacteriological quality - Guidance for establishing and verifying a conversion relationship between routine method results and anchor method results.

14. MEST EN ISO 6888-2 (2008): Microbiology of food and animal feeding stuffs - Horizontal method for the enumeration of coagulase-positive staphylococci (Staphylococcus aureus and other species) - Part 2: Technique using rabbit plasma fibrinogen agar medium.

15. MEST EN ISO 4833 (2008): Microbiology of the food chain - Horizontal method for the enumeration of microorganisms - Part 2: Colony count at 30 degrees $\mathrm{C}$ by the surface plating technique.

16. Mijačević, Z., Babić, Lj., Stojanović, L. (1990): Uticaj tehnoloških operacija, sastava i osobina mleka na kvalitet i količinu kajmaka u eksperimentalnim uslovima. Mljekarstvo 40 (11), 295-306.

17. Mirecki, S., Adžić, N. (2000): Higijenska ispravnost i hemijski sastav crnogorskog skorupa. Poljoprivreda $i$ šumarstvo 46 (1-2), 67-77.

18. Mirecki, S., Antov, G. (2002): Tehnologija i kvalitet crnogorskog skorupa. XVII Savetovanje: Savremeni pravci razvoja u tehnologiji mleka. Prehrambena industrija, 68-73. Novi Sad.

19. Official Gazette of Montenegro (2011): Law on protected designation of origin, protected geographical indication and traditional speciality guaranteed. No. $18 / 11$.

20. Official Gazette of Montenegro (2012): Rules on Microbiological Criteria for Food Safety. No. 53/12.

21. Sabadoš, D. (1996): Kontrola i ocjenjivanje kakvoće mlijeka i mliječnih proizvoda. Udžbenik Sveučilišta u Zagrebu. 2. dopunjeno izdanje. Hrvatsko mljekarsko društvo. Zagreb.

22. Stanišić, M., Bijeljac, S., Sarić, Z., Jovanović, S. (1990): Korelativni odnosi u tehnologiji kajmaka. Mljekarstvo 40 (10), 259-264. 